\title{
Geomorphology Using Geographic Information System and Globel Mapper
}

\author{
Emad Akawwi \\ Department of Surveying and Geomatics, Engineering Faculty, Al-Balqa Applied University, Salt 19117, Jordan
}

Received 2013-09-02, Revised 2013-09-13; Accepted 2013-09-18

\begin{abstract}
An effort has been made to evaluate drainage morphometry and its influence on landform processes, geology and erosion characteristics in Jordan Valley and surrounding area. Geological maps 1:50,000 scale and the professional Google Earth images were used for analysis of various morphometric, lithological and landform characteristics of Jordan Valley basin. Morphometric analysis was carried out at sub basin level using Geographic Information Systems (GIS) and Globel Mapper (GM) to analyze the influence of drainage morphometry on landforms, drainage pattern and land erosion. Different landforms were recognized in the basin based on visual exposition of 3D Digital Elevation Model (DEM) that obtained from the thousands of points of the elevations by using GIS and GM, escarpments, plateau spurs, narrow wadies "vallies" and main wadies floor, foot slopes. The sub basins that take number 2, 5 and 6 are associated with high density dentritic drainage pattern because of impermeable formation and high slope then high surface runoff and high erosion. The sub basins number 1, 3, 4 are associated to a low density dentritic drainage pattern due to the topography of the area that is flat shape and the formation is impermeable. A1, A2 and A3 are a trellis drainage pattern with high density because of the moderate slope and high fracturing formation.
\end{abstract}

Keywords: Drainage, GIS, GM, Jordan Valley, DEM

\section{INTRODUCTION}

Erosion of soil and the underlying regolith is an example of a natural process that can be strongly accelerated by land use-human being activities and climate changes. Drainages erode their beds in three ways. The first one is the difference of the topography, the second way is the scrape and the third one is the solution. Streams can change from one season to the other depending on the precipitation and the difference on the temperature. Because that, it's very useful to describe the aspects of the stream and its variables. The stream variables including velocity, slope or gradient, the shape of the drainage and densities and streams discharge. The remote sensing and GIS techniques were used by (Vijayan et al., 2013) for determining the quantitative description of the basin geometry.

In GIS, the stream network is represented by a network of connected line features, which can be digitized from topographic maps or (semi-) automatically derived from a Digital Elevation Model (DEM) (Talling et al., 1997; Soille et al., 2003; Vogt et al., 2003; Abubaker et al., 2012). Similarly, the associated watersheds are represented by polygon features. Using consistent GIS tools on the same DEM to derive both streams and watershed divides results in geometrically consistent datasets of streams and watersheds. Manually digitized data often require time-consuming editing. In any case, basic GIS functionality leaves the hydrologist with separate, geometrically consistent datasets of the stream network and watersheds, but the inherent hierarchy determined by the tree structure of a stream network is not automatically captured. There are ongoing initiatives representing surface topography accurately and effectively is critical to support various types of inquires in geography and geosciences. The digital elevation models were used by many researchers for various applications, for instance flood control and hazard mapping (Wise, 2000; Bower, 2010). Chu et al. (2010) delineated the watersheds by developing algorithm. 
Therefore, DEMs and related algorithms afford the basics of scientific inquiries associated to topography and environment. A major use of DEM data in Earth Science is in hydrologic analysis. However, many hydrologic studies fail to provide consistent results. Some studies attribute the differences to factors such as data sources, spatial resolutions of DEMs and the adopted algorithms in analyzing the data (Baker et al., 2006).

The deformation creates relief in mountain chains are much more quickly than in other geodynamic environments. The relief formation quantification that is issued by tectonics and its effects on the landscape evolution is a subject of much interest. Particularly, the study of geomorphological features can be extremely useful in reconstructing the tectonic evolution and uplift of an area. The deformation/erosion balance in mountain ranges is clearly positive (Mather, 2000; Stokes and Mather, 2003; Vernant et al., 2013).

The purpose of this study is to use geomorphological, geochronological and structural data to:

- Describe the morphological evolution of the drainage pattern of the eastern part of the Jordan Valley and to discuss its tectonic meaning

- Constrain the geometry of the surface water subcatchments along the Jordan River

The study area locates in Western part of Jordan. It situated to the north west of Arabian Peninsula, separated from Israel and Palestine by the Dead Sea Rift Valley that extend from Gulf of Aqaba to Tiberius pass through Wadi Araba, Dead Sea and Jordan Valley (Fig. 1). This study was carried out for the western margin of Jordan, the eastern side of the Jordan River the Northern part of the Jordan Rift (Lower Jordan Valley). In the west, the Jordan Rift Valley depression with an average elevation of 250 meters below sea level runs along the full length of Jordan on $360 \mathrm{~km}$. It encompasses from the north (Lake Tiberius) to the south (Red Sea) the Jordan Valley, the Dead Sea and the Wadi Araba. The mountains running alongside the Jordan Rift valley (called Uplands in this synthesis). They cross the country from north to south with a width of 30 to $60 \mathrm{~km}$. Their altitude reaches $1,000 \mathrm{~m} 3$ above sea level in the LJRB. Mountains gradually slope to the east and south.

The coordinate of the study area is between $31.75^{\circ}$ and $32.75^{\circ} \mathrm{N}$ and between $35.5^{\circ}$ and $36.00^{\circ} \mathrm{E}$. The climate of the study area is defined as a semi-arid at the mountain in the study region with average precipitation of $550 \mathrm{~mm} / \mathrm{y}$ and temperature between -5 Celsius in the winter and 38
Celsius in summer season. The climate at the area adjacent to the Jordan River is arid climate with average precipitation about $100 \mathrm{~mm} / \mathrm{y}$ and temperature between 4 Celsius in winter and 45 Celsius in the summer season.

The geology and the structural issue in the study area can be explained as the following; Top Turonian in Jordan is named as top Ajlun group which, extend from base to top, the Na'ur undifferentiated limestone, Fuhais, Hummar marly limestone, Shua'ib and Wadi Es-Sir limestone formations (Powell and Moh'd, 2011). The latest formation is a top Ajlun group and it consider as a middle aquifer which consists of massive limestone. The period of the late cretaceous to Early Tertiary is well known for extension deposition of phosphoric on carbonate platforms at the southern margin of the Tethys Ocean that extend from Turkey to Morocco. It passes through Israel, Palestine, Jordan, Syria, Iraq, Saudi Arabia, Egypt, Tunisia and beyond the Atlantic to Colombia and Venezuela (Parrish and Curtis, 1982). After the compression event, extension within the Arabian plate during the Late Cretaceous to early Tertiary caused the formation of a series of northwesttrending basins (Bender, 1974). Later left-lateral strikeslip faulting along the Dead Sea Transform in the Neogine led to the development of well defined pullapart basins such as the Dead Sea Basin.

From the Late Cretaceous to Eocene Jordan was covered by an extensive marine transgression from Cenomanian time, in relation with a global warming event, which resulted in the deposition of the Ajlun and Belqa groups (Bender, 1974). During the Late Eocene, a regression led to a period of folding, uplift and erosion. This period is also characterized by a left lateral transtensional event which were responsible for the Dead Sea rifting, extensive basalt flows mainly in north-east Jordan, but which extend to Syria and Suadia Arabia and by localized lacustrine and fluviatile deposits in the Azraq and Jafr basins.

\subsection{Lithostratigraphy}

The base of the carbonate platform represented by the Late Turonian which named in Jordan by Wadi EsSir Limestone formation (WSL) unconformably overlain by the Belqa Group. The area investigated, in the west-central Jordan was part of a carbonate platform, situated on a broad, shallow shelf on the northern margin of the A rabo Nubian Shield. Late Albian-Turonian platform deposits are dominated by marls and clays, alternating with limestone and dolostones, with subordinate siliciclastic. 


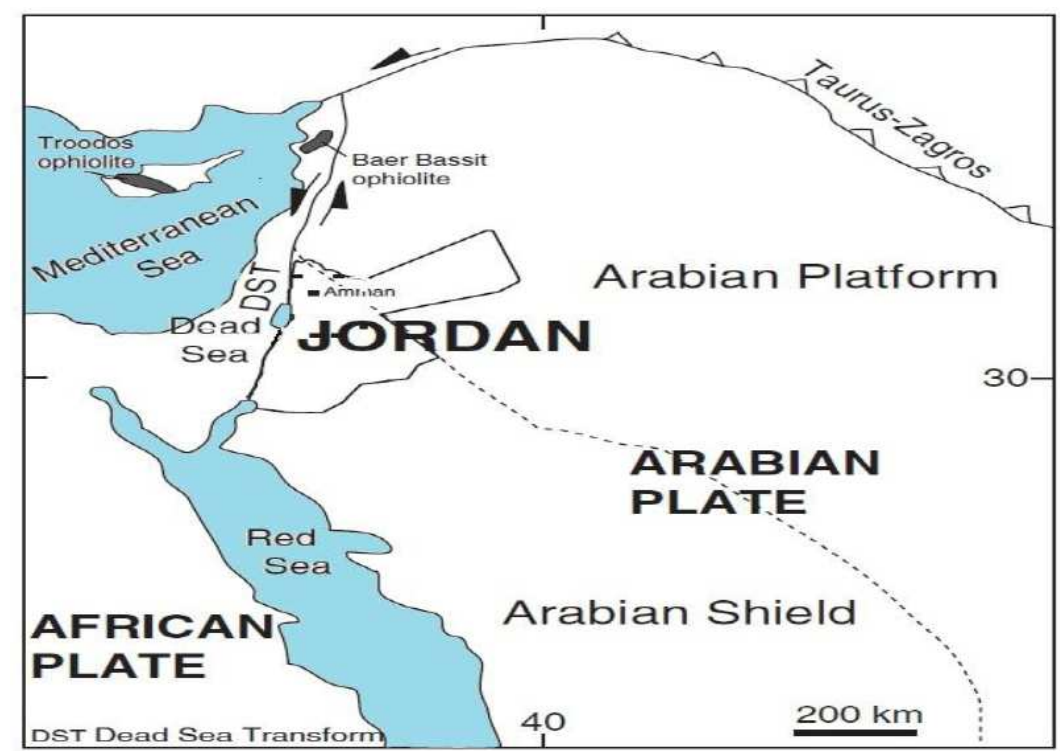

Fig. 1. The structural map of the middle east shows the boundaries between Arabian plate and African plate

The Precambrian and Palaeozoic units are only exposed in South. They are unconformably overlain by Mesozoic sediments, which cover large areas of the country. Cenozoic sedimentary deposits are widely distributed and exposed throughout Jordan. A Neogene and Quaternary sheet basalt province covers large areas of northern Jordan (Bender, 1974). During Cretaceous to Eocene time and for much of the early Mesozoic, Jordan lay at the southern margin of the Neo-Tethys Ocean which episodically transgressed, south and east, over the margins of the Arabian Craton (Powell and Moh'd, 2011).

Thick successions of Eocene marine shelf carbonate ramp facies are marked by widely distributed outcrops in Jordan. On the other hand, the Lower Oligocene outcrops are patchy, occurring as a thin belt and limited to the marginal marine facies. These Paleogene carbonates exhibit rapid facies changes in Jordan resulting from (Farouk et al., 2013). The Paleogene deposits are represented by a large carbonate platform and ramp with deepening of the depositional basin observed toward the northern part of the Arabian and African plates.

A major marine transgression occurred during the Paleocene, such that shallow marine shale or limestone often unconformably overlies the older formations covering the eastern Arabia and the entire northern part of its shelf. Transgression continued until the early Middle Eocene, at which time only western Saudi Arabia, parts of uplifted ranges of Iran and Iraq and Semail and Hawasina Mountains in Oman remained in emergent position (Guiraud and Bosworth, 1999). During the Late Eocene, most of the Arabian Shelf and South Africa were raised up into a continental landmass and deposits of the Early Oligocene global marine regression are found only in portions of the shallow marine facies in the lowland areas of the Africa and Arabian platforms towards the north (e.g., northern part of Egypt and Libya, Syria, north Iraq, Oman, United Arab Emirates). Whittle et al. (1995) reported that during the Middle and Late Eocene times, a major regression took place associated with a large uplift in Arabia and Iran exposing all of that area for extensive erosion. Such conditions are also recorded by (Abdulsamad et al., 2009) in the Benghazi area (NE Libya) where, the Lower Oligocene unconformably overlies Middle Eocene sediments. The broader regional effects of this tectonic activity across the Eocene/Oligocene unconformity are observed in many countries of the Arabian plate, including Saudi Arabia, Kuwait, Bahrain, south Iraq, Qatar, where the Miocene deposits lies directly above the Middle Eocene Dammam Formation (Alsharhan and Nairn, 1995). The active deformation associated with large continental faults often displays prominent tectonic landforms mainly due to the occurrence of successive large earthquakes in the past. The north-south trending left lateral Dead Sea transform Fault (DSF), a 1000-km long major plate boundary accommodates most of the active deformation between the Arabian and African-Sinai plates 
(Fig. 1). Taking the historical seismicity of the region into account (Ambraseys and Jackson, 1998; Sbeinati et al., 2005), the fault was likely the source of several large earthquakes (MN7) with severe damage, surface faulting and landscape changes. A segment of the DSF zone that shows pull-apart basins and transpressive ridges along strike is well exposed in the Jordan Valley where it extends from the Dead Sea to the Lake Tiberius (Sea of Galilee).

The late Pleistocene and Holocene lacustrine deposits and related drainage network that cover the major part of the rift valley, likely constitute a geological archive of the successive fault movements. Previous estimates of slip rates along the DSF vary from 2 to $10 \mathrm{~mm} / \mathrm{yr}$ (Galli, 1999; Garfunkel et al., 1981; Niemi et al., 2001). According to historical documents, the most recent large earthquakes along the Jordan Valley Fault (JVF) occurred in $749 \mathrm{AD}$ and $1033 \mathrm{AD}$ and severely damaged ancient cities of the Jordan Valley (Guidoboni et al., 1994). Earthquakes are also reported at the archaeological sites of Pella, Jerash and Tell El-'Umayri' (near Amman) (Marco et al., 2003; Sbeinati et al., 2005) and testify to the long-term seismic activity in the Jordan Valley area. These historical and pre-historical earthquakes may have produced surface faulting with significant cumulative left-lateral offsets.

The available high-resolution stratigraphic sequence is a key factor for the understanding of geological phenomena in the valley. Pleistocene formations display varied lacustrine sediments of Lake Lisan, a precursor of the Dead Sea. Locally, the retreat of Lake Lisan was followed by the late Pleistocene onset of the freshwater Lake Damya (Abed and Yaghan, 2000). The Lisan and Damya formations have been the subject of extensive geological and geochemical studies that provide extremely detailed stratigraphic descriptions along with $\mathrm{U}-\mathrm{Th}$ and $14 \mathrm{C}$ ages ranging from $63 \mathrm{ka} \mathrm{BP}$ to $12 \mathrm{ka} \mathrm{BP}$ (Bartov et al., 2002; Landmann et al., 2002) northeast of the Dead Sea in the Ghor Katar area. Lacustrine units consist in horizontal lamina visible across large areas in wide incisions where local variations are due to landslides, seismicity and back tilting against normal faults. The erosional process responsible for the drainage network (gullies) is mainly controlled by the down-drop of the lake water level and reflects paleoclimatic fluctuations. Therefore, the combined analysis of visible geomorphologic processes and detailed description and dating of late Pleistocene-Holocene sedimentary units allow for a high-resolution paleoclimatic reconstruction. (Bookman et al., 2004) provide a high-resolution record of lake-level fluctuations during the Holocene showing strong gradients involving rise or fall episodes of $\sim 50 \mathrm{~m}$ in $500 \mathrm{yr}$ periods (i.e., at a rate of $10 \mathrm{~cm} / \mathrm{yr}$ ) and correlate those level fluctuations with intense rainfall episodes triggered by large-scale atmospheric circulation. Historical earthquakes in the area are well documented in the medieval times and the location of maximum damage zones is accurately known.

\section{MATERIALS AND METHODS}

Arc GIS 9.3 (Arc-GIS 9.3 for GIS applications, produced by ESRI, Redlands, USA) that was used in this research, is a computer program used to generate, demonstrate and analyze geospatial data. The GIS consists of three components: Arc Map, Arc Catalog and Arc Toolbox. Arc Map is used for visualizing spatial data, performing spatial analysis and generating maps to show the work results. While, Arc Catalog is used for browsing and exploring spatial data, as well as viewing a creating metadata and managing spatial data. Arc Toolbox is an interface for accessing the data conversion and analysis function that come from Arc GIS. This software was used to create a mosaic map of eight geological map sheets of scale 1:50,000 as shown in Fig. 2 and was used for delineate the drainage pattern of the study area in cooperation with satellite images that were gotten from the Google Earth 2012. This software was used for creating the streams and drainage pattern for the study area by using the Arc-Hydro GIS extension. Arc Hydro Groundwater is a conceptual design implemented from an Arc-GIS geo-database model. Arc Hydro Groundwater (AHGW) expands Arc-GIS software with groundwater and subsurface geo-processing tools developed in collaboration with Environmental Systems Research Institute, Inc (ESRI).

GM8 is a software tool from Global Mapper Software (http://GlobalMapper.com) enabling creation of digital maps. GM8 has the ability to load and display overlays concurrently. This means that you may have a reference map loaded in a raster overlay, from which you can trace or digitize features in a vector overlay. GM8 has built in functionality for distance and area calculations, raster blending, spectral analysis, elevation querying, line of sight calculations, cut-and-fill volume calculations, as well as advanced capabilities like image rectification, contour 6 generation from surface data, view shed analysis, watershed delineation, terrain layer comparison and triangulation and gridding of 3D point data. GM8 can be used for the watershed calculation tool determines the likely linear path of streams and the drainage or catchment areas of those streams. 


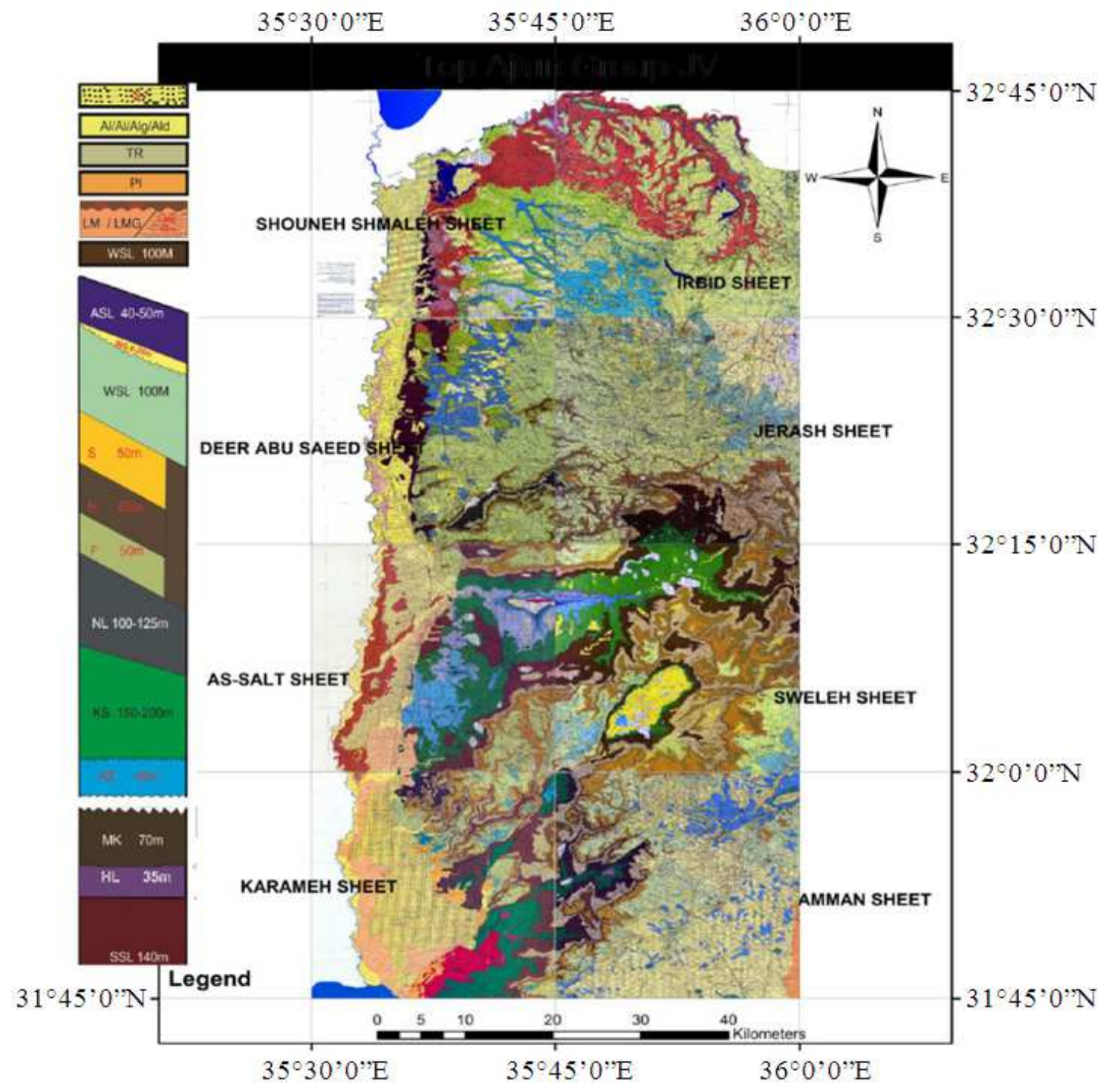

Fig. 2. The mosaic of the geological sheet maps that cover the study area. Eight geological sheets were used in this study. The names of the sheets are Karameh, Amman, Al-Salt, Swelih, Deer Abu Saed, Jarash, Shwaneh Shmaleh and Irbid

Globel Mapper (GM8) and Geographic Information Systems (GIS) can be used also to build three-dimensional models for any geographical location on the surface of the Earth. The representation of terrain topography of any site needs data form three-dimensions $(\mathrm{z}, \mathrm{y}, \mathrm{x})$, which is known as Digital Elevation Model (DEM). Thus, the applications of DEM is well pronounced in several applications and more certainly to induce many components, such as slope, sunlight exposure, drainage systems, low-lands. The concept behind establishing DEMs implies the treatment of elevation points whether from digital contour lines or from Google Earth (e.g., Geo-Eye images) or any other satellite images. Hence, Triangulated Unregulated Network (TIN) must be primarily constructed, which represents digital data structure used in GIS of surface attributes of the physical land surface or sea bottom, 
made up of irregularly distributed nodes and lines with three dimensional coordinates ( $\mathrm{X}, \mathrm{Y}$ and $\mathrm{Z}$ ) that are arranged in a network of non-overlapping triangles. TINs are made from mass points, breaklines and polygons. Mass points are height points; they become nodes in the network, thus they primary input into a TIN in order to determine the overall shape of the surface. Currently, the use of Digital Elevation Models (DEM) has found widespread applications in several geomorphologic and hydrological purposes; especially that this technique allows the extraction of topographic features of the earth surface making possible the display of all natural features for the both vertical and horizontal resolutions. However, DEM extraction requires elevation data for topographic features with geographic coordinates of each elevation. In this study, Geo-eye-1 satellite images, with $2 \mathrm{~m}$ precision were used. In this study, after establishing the DEM, the resulting data was analyzed to recognize the wadies slopes and depressions.

\section{RESULTS}

GM8 renders a perspective 3D view of the study area. as shown in Fig. 3, combining the elevation data that obtained from the field surveying by using differential GPS.

When the topographic contour lines have been generated, GM8 created a new overlay called generated contours that created from the GPS survey as shown in Fig. 4.

Elevation Data were used to create topographic contour lines. The GM8 software was used to create a Digital Elevation Model for the topography (DEM) as shown in Fig. 5 and slope aspect map in Fig. 6.

Hydro network was created from the base map was obtained from the Google earth image 2012 (Geo-Eye satellite image), using the Arc Hydro framework data model in Arc-GIS and the tools coming with Arc Hydro.

This object-oriented model establishes a topological network and cross-layer topological relationships between water-sheds, streams and junctions (Fig. 7). The network topology defines the flow direction, connectivity and upstream/downstream relationships of stream segments. However, the Arc Hydro framework data model and the tools are based on the Arc-GIS Geodatabase (Zeiler, 1999), which is a proprietary format. The "Hydrojunction" shape file collects all stream junctions (nodes). The stream segments are held in a "Hydroedge" line shape file and the watersheds are in the polygon shape file "Watershed".

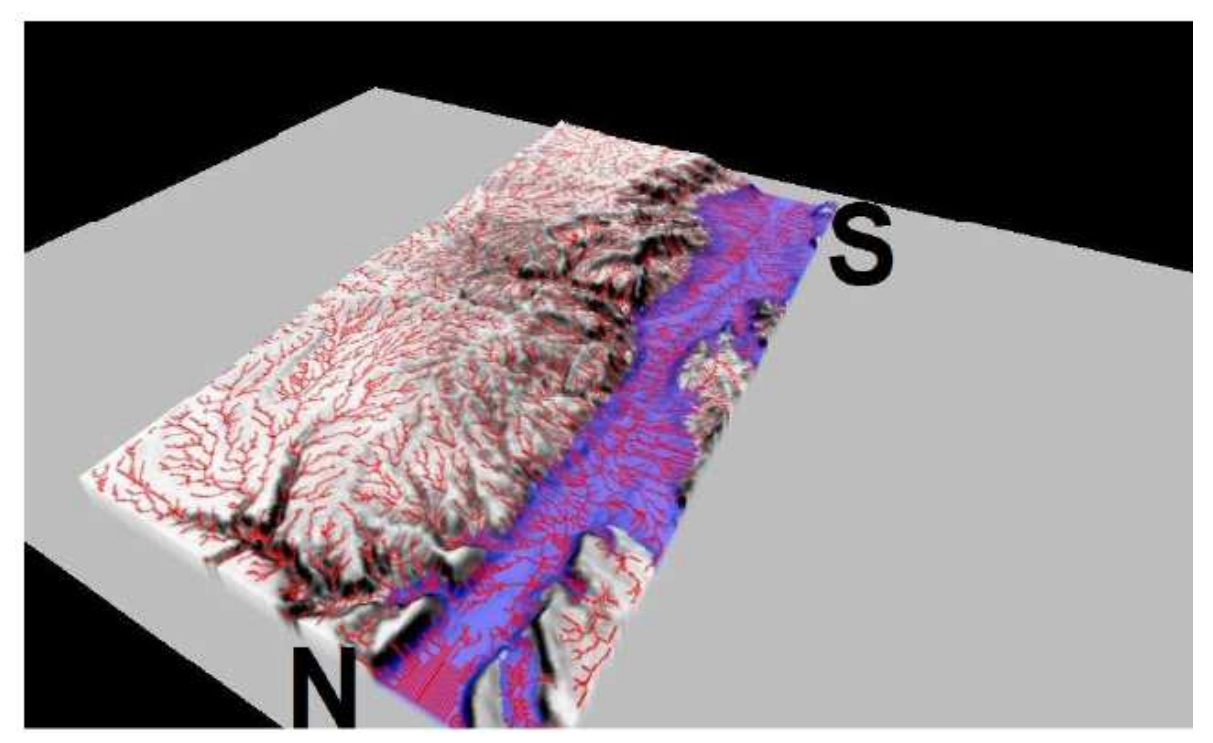

Fig. 3. The 3D model of the study area including the drainage and the streams. The Northern part of this figure is the Taberius (Sea of Galleli) and the southern part is the north corner of the Dead Sea. Most of the streams are discharging into the Jordan Valley and some of them are discharging into the northern part of the Dead Sea 


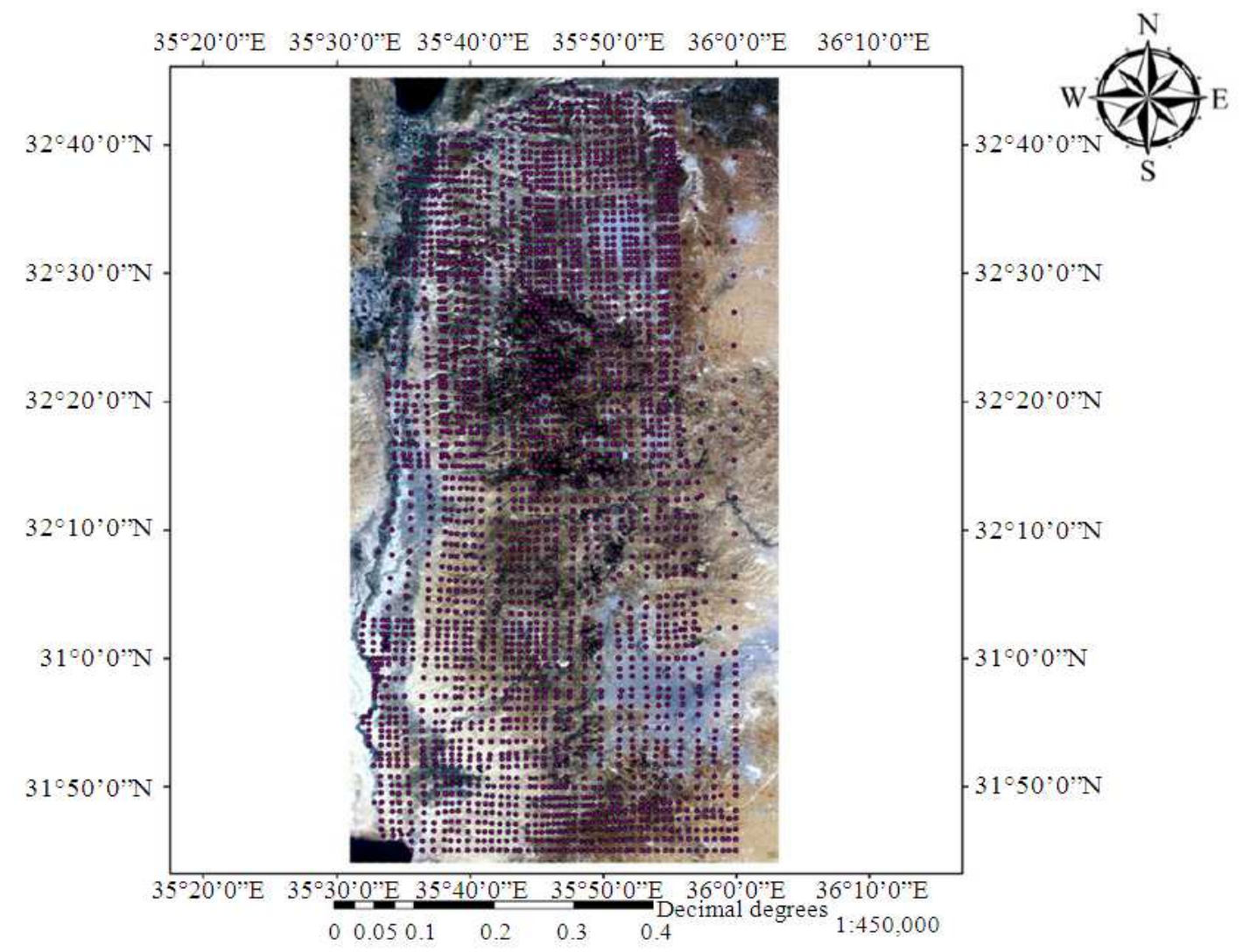

Fig. 4. The Google Earth Image 2012 with the locations of GPS points (Green Dots) of the elevation values

\section{DISCUSSION}

There are several side wadies in the study area that are defined as temporary streams. These wadies have lesser importance than the larger rivers that discharged into the Jordan River. One of these rivers is Zarqa River that comes from the eastern highland and feed the lower Jordan River. Morphology of the drainage network, in particular in the Jordan Valley are a trellis pattern and dendritic pattern. The first corresponds to the active drainage basin of the AlYarmouk River and Azraq River. Drainage texture within any one small area in which climate, topography and erosion history are reasonably constant commonly may be indicative of the permeability of materials or of the size of particles provided by weathering. Individual stream patterns may provide information on structural features, rock type, the permeability and porosity of the rocks, or geomorphic changes.
The Yarmouk River is the main tributary of the Lower Jordan River and the main surface water resource of the country. The Yarmouk is also the border between Jordan and Syria and the river is fed by springs and wadies mainly originating in Syria. The Zarqa River is the second main tributary of the study area. This river discharging in the west of Amman, flows eastwards to the town of Zarqa, then join the Wadi Dhuleil at the northwards, then draining westwards into the Jordan Valley.

The main branches of the trellis network are within Al-Yarmouk River in sub-basin 1 is denoted by A1, within Zarqa River sub-basin 3 is denoted by A2 and at the foot of the Jordan River sub-basin 4 is denoted by A3. The sub-basins 3 and 4 are flow from the Western Salt Mountains and Jarash Mountains respectively to the Jordan Valley as shown in Fig. 7. The geological formations of theses Trills drainage patterns are demonstrated with permeable and high porous sandstone through the wadies paths with low surface flow. 


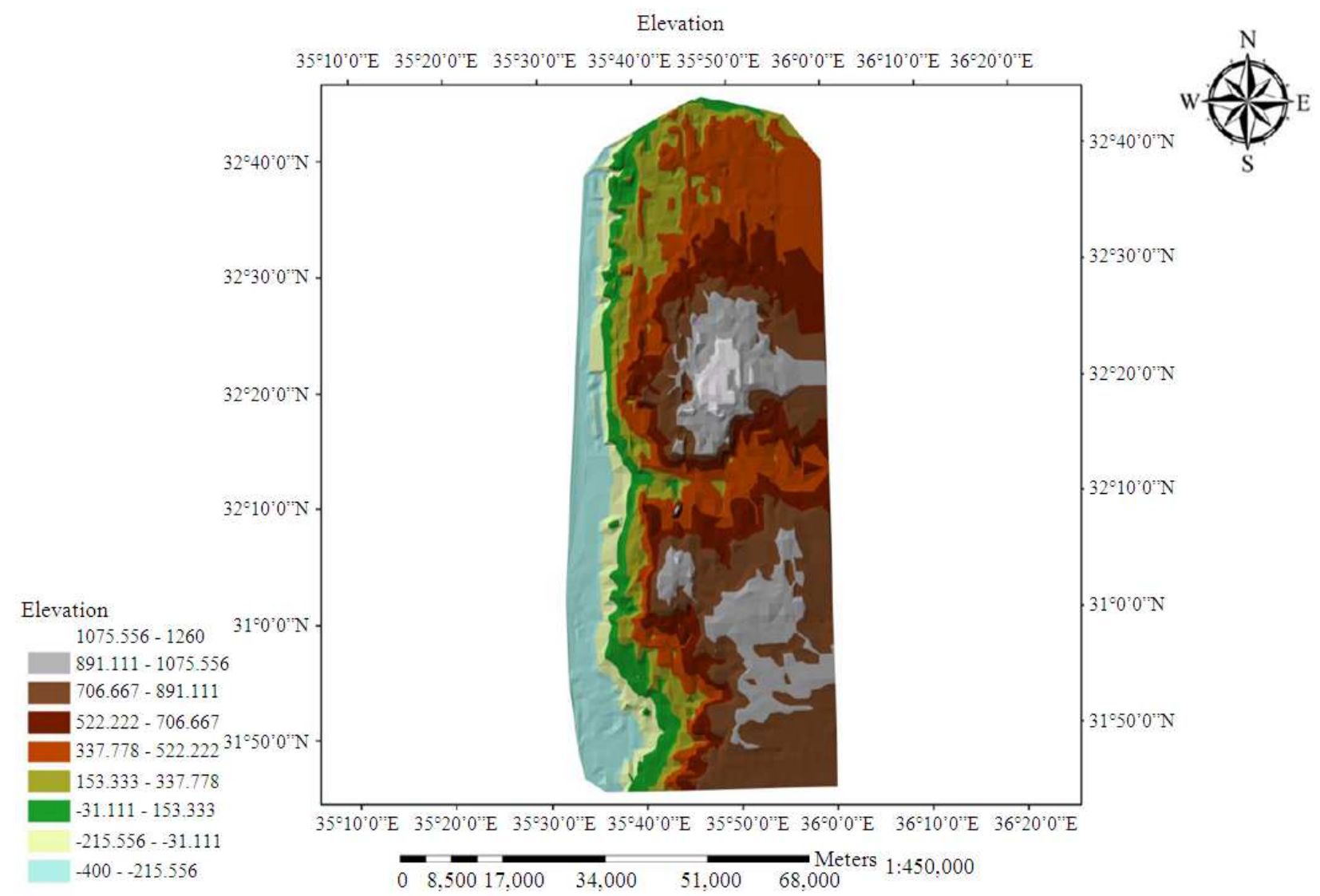

Fig. 5. The digital elevation model of the topography elevation of the study area. Shows that the elevation in the study area between$420 \mathrm{~m}$ below main sea level at the Jordan Valley and 1600m above mean sea level at the northern highlands

The Al-Yarmouk River and Azraq River lie subparallel, E-W-to NE-SW-oriented and separated by about $55 \mathrm{~km}$. In the western slope of the Western Jordan, the catchment of these Wadies forms two high density dendritic hydrographic networks as shown in Fig. 7. These dentritic networks is very well developed in the interfluves zones of the sub-basins number 2 and 5 between Al-Yarmouk River and Zarka River and between Zarka River and Wadi Shua'ib in the southern part of the study area respectively. The network is very well structured; each catchment is composed of high tributaries of similar dimensions. The confluence angles are acute (with about $12 \%$ ). The geological formations described as highly fractured limestone and sandstone intercalated with high content of clay and marl that reduced the permeability and increase the surface runoff. Zarqa River catchments are essentially adjusted to the topography and the tectonic structure with catchment basin about $900 \mathrm{Km}^{2}$.
The surface of the Wadi Kafrein catchment basin denoted by number 6 in Fig. 7 is about $189 \mathrm{Km}^{2}$. It is located at the southern part of the study area to the west of Amman and some parallel Wadies are partially filled middle-late Miocene fluvial deposits. These Wadies link with the Central Depression at -100-200 m altitude and are continued across the crest of the Wadi Essir and $\mathrm{Na}$ 'ur towns that reaches $1100 \mathrm{~m}$ altitude. The dendritic pattern trends east-west direction. It shows incisions practically orthogonal and it evenly distributed along the fault systems. From Satellite images were obtained from Google Earth and field observations and depth analysis of gullies a positive relationship between faulting and drainage development was observed. The surface water in this catchment is discharge directly to the Dead Sea. The drainage pattern of this sub-basin is highly dentritic. This drainage type is due to the geological formations, which are a marly limestone interbedded with clay and marl and the slope is about $10-15 \%$. 


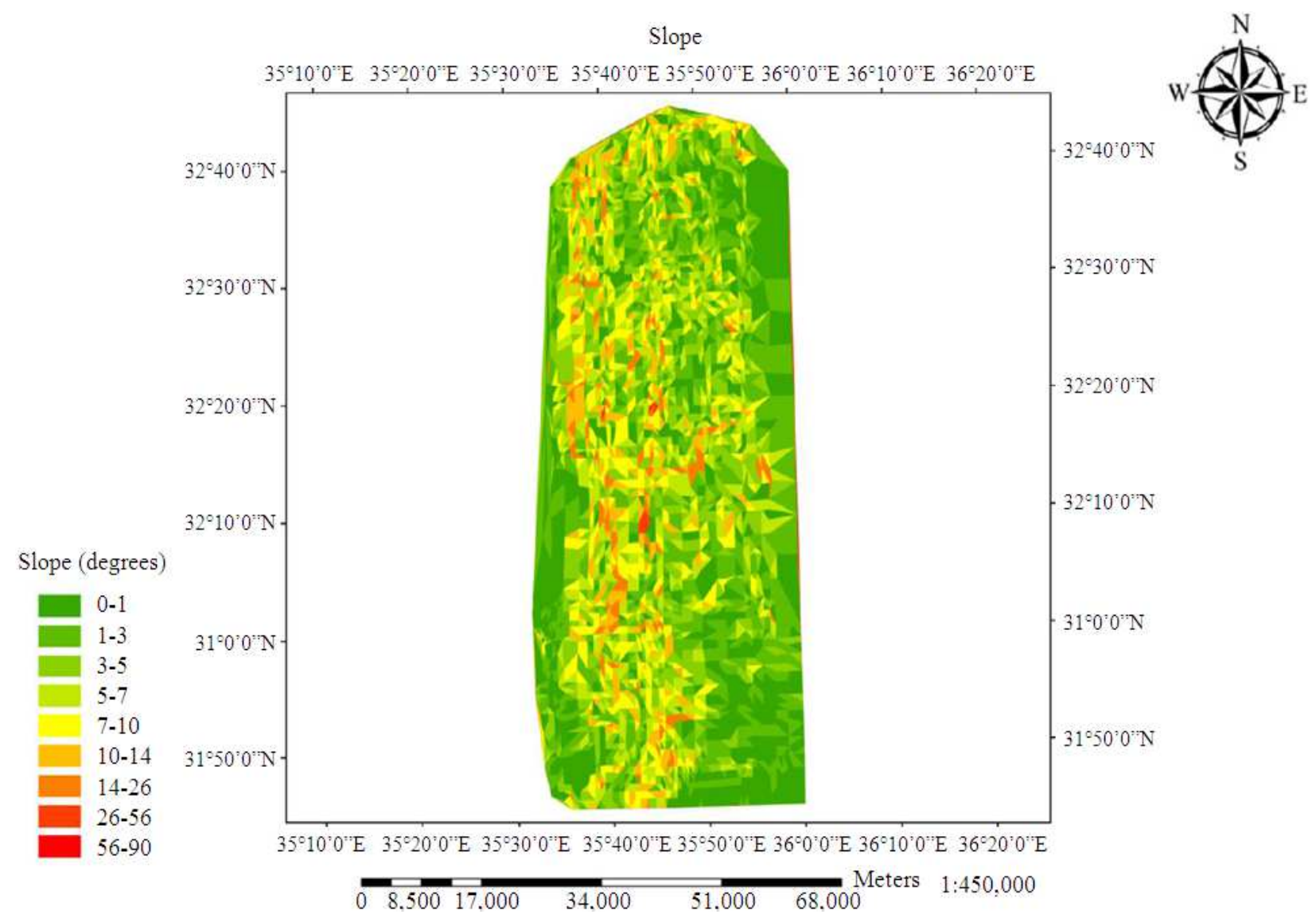

Fig. 6. The slope aspect map of the study area. This figure shows that the slope is between 3 and 60 degree. The slope at the northern highlands is ranging between 12 to 20 degree the slope the foot of the Jordan Valley is about 30 degree

The DEM Fig. 5 and the slope aspect maps Fig. 6 show that the farther Eastern side of the Jordan Valley area show that the highest elevation of 1000-1260 m from mean sea level $(\mathrm{msl})$ is related to mountainous at the northern highland located at Ajlun, Sweleh and Amman cities. The slope of this area is between 10$26 \%$ covering an area less than $10 \%$ of the study area and the main geological formation is Limestone from top Turonian age at the middle part and southern part of the study area. While the elevation ranging from 600 to $1000 \mathrm{~m}$ above mean sea level dissected hills and escarpments in the Amman, Sweleh, Salt, Jarash, Ajlun cities with slop about $10 \%$ covering an area of $50 \%$ of the study area and the geological formation mainly Limestone from Cenomanian and Turonian ages. The area with elevation ranging from 400 to 600 $\mathrm{m}$ above $\mathrm{msl}$ is related to flat area at Irbid at the northern part of the study area and the valies upper streams at the highland of Jarash and lower streams at
Jordan Valley. The geological formations at the bottom of this wadi consists of Kurnub sandstone from lower cretaceous age and the wall of this wadi consists of undifferentiated of Fuhais/Hummer/ Shua'ib formations from Turonian age and the slope is about $10 \%$ covering about $10 \%$ of the study area. An elevation between-200 m below sea level to about 200 $\mathrm{m}$ above mean sea level is escarpments along the Jordan River with slope about $7-10 \%$ and covers an area about $10 \%$ of the study area. The outcropping geological formation of this area is Na'ur formation lowers Turonian at the northern part of the study area and Alluvium from the recent age at the middle and southern part of the study area. Finally the elevation below-200 m below mean sea level is associated to flat area adjacent to the Jordan River and main Jordan River floor with slope of $0-3 \%$ covering area of $20 \%$ and the outcrop geological formation is Wadi Sediments, Alluvium and Lisan formations from the recent age. 


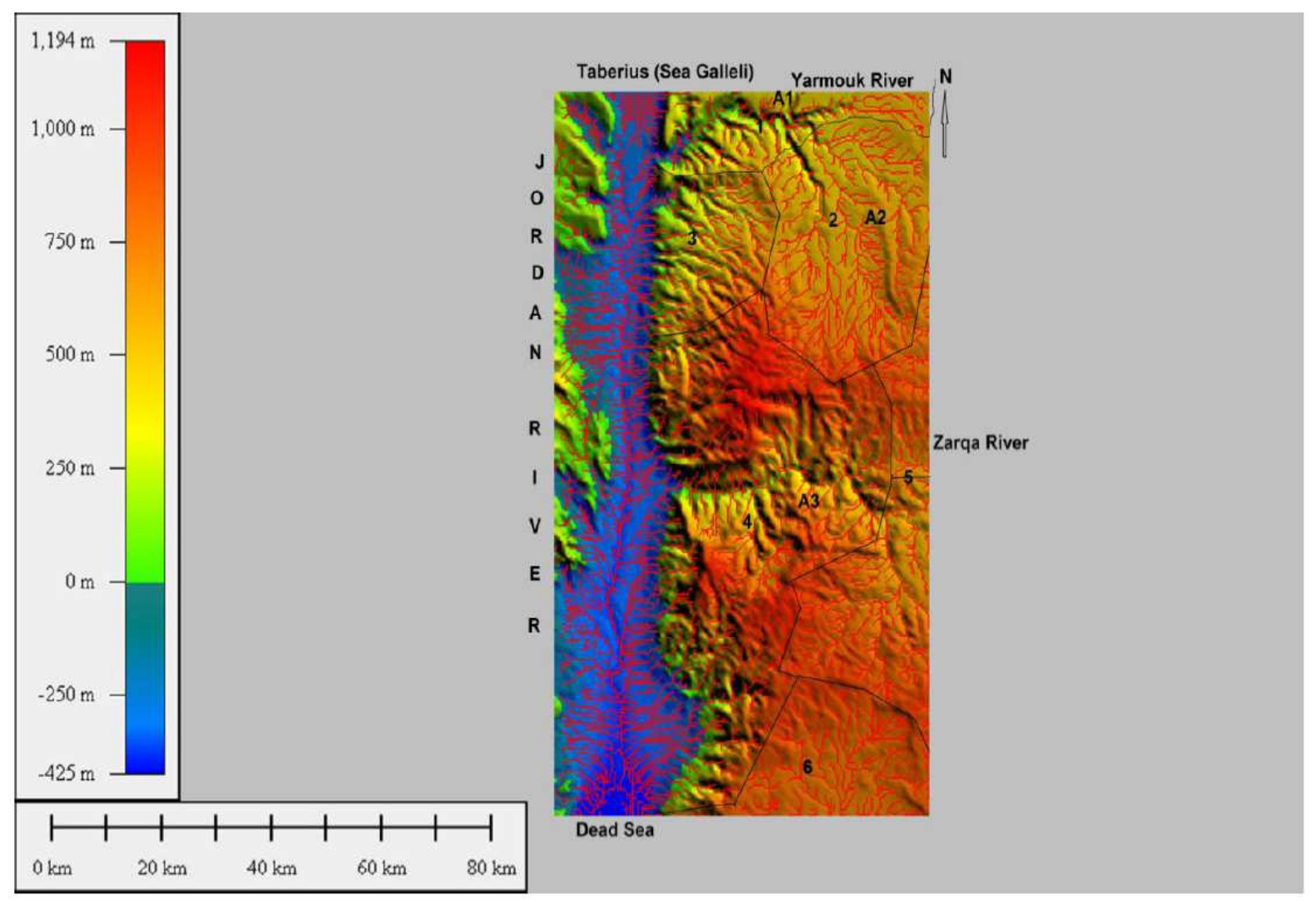

Fig. 7. The drainage pattern, streams and sub catchments of the Jordan River area. The numbers from 1 to 6 denote to the sub catchments. The numbers and letters A1, A2 and A3 denote to the Trills drainage pattern

The Limitations of this study are reporting as the following: the working on the whole Jordan Valley is very difficult because the area have varies conditions including the climate, the slopes, the elevations that have high difference and varies of the geological formations. Then the best study is to divide the area into many subareas and work with each subarea separately.

There are good correlations between the results of current study and the results were found by Ramasamy et al. (2011) and Keller and Derecchio (2013) about the affect of the tectonic on the drainage pattern. The results from this study are coinciding with results were obtained by Nobre et al. (2011) about the relationships between the geological formations and the drainage systems.

\section{CONCLUSION}

- The main two drainage patterns in the study area are dentritic and trellis
- The trellis drainage pattern were found at the Yarmouk River and Zarqa River

- The dentritic drainage pattern covered most of the Jordan River area with about $80 \%$

- The high density dentritic drainage pattern were found at area with high slope and the high clay and marl contents

- The main outcropping geological formations in the study area are Wadi Essir formation (Top Turonian age) and the undifferentiated Fuhais/Hummer/ Shua'ib (Cenomanian age)

- The slopes of the area are different from 3\% at the foot of the Jordan Valley and 26\% at the highland area at the east of the Jordan Valley

\section{ACKNOWLEDGEMENT}

I would like to express my thanks to Prof. Dr. Abdallah Al-Zoubi from Al-Balqa Applied University for his supporting to do this research. 


\section{REFERENCES}

Abdulsamad, E.O., F.M. Bu-argoub and A.F.A. Tmalla, 2009. A stratigraphic review of the Eocene to miocene rock units in the al Jabal al Akhdar. NE Libya. Marine Petroleum Geol., 26: 1228-1239. DOI: $10.1016 /$ j.marpetgeo.2008.06.003

Abed, A.M. and R. Yaghan, 2000. On the paleoclimate of Jordan during the last glacial maximum. Palaeogeogr. Palaeoclimatol. Palaeoecol., 160: 2333.

Abubaker, T., E.A. Azra and C. Mohammed, 2012. Selecting suitable drainage pattern to minimize flooding in sangere village using GIS and remote Sensing. Global J. Geol. Sci. DOI: 10.4314/ gjgs.v10i2.1

Alsharhan, A.S. and A.E. Nairn, 1995. Tertiary of the Arabian Gulf: Sedimentology and hydrocarbon potential. Palaeogeography Palaeoclimatol. Palaeoecol., 114: 369-384. DOI: 10.1016/0031-0182 (94)00089-Q

Ambraseys, N.N. and J.A. Jackson, 1998. Faulting associated with historical and recent earthquakes in the eastern Mediterranean region. Geophys. J. Int. 133: pp 390-406. DOI: 10.1046/j.1365-246X.1998. 00508.X

Baker, M.E., D.E. Weller and T.E. Jordan, 2006. Comparison of automated watershed delineations: Effects on land cover areas, percentages and relationships to nutrient discharge. Photogrammetric Eng. Remote Sens., 72: 159-168.

Bartov, Y., M. Stein, Y. Enzel, A. Agnon and Z.E. Reches, 2002. Lake levels and sequence stratigraphy of lake lisan, the late pleistocene precursor of the dead sea. Q. Res., 57: 9-21. DOI: 10.1006/qres.2001 .2284

Bender, F., 1974. Geology of Jordan. Gebrueder Borntraeger, 1st Edn., Gebruder Borntraeger Verlagsbuchhandlung, Science Publishers, Berlin, ISBN-10: 3443117074, pp: 196.

Bookman, R., Y. Enzel, A. Agnon and M. Stein, 2004. Late holocene lake levels of the dead sea. Geol. Soc. Am. Bull., 116: 555-571. DOI: 10.1130/B25286.1

Bower, S.S., 2010. Natural and unnatural complexities: Flood control along Manitoba's Assiniboine River. J. Historical Geography, 36: 57-67. DOI: 10.1016/j.jhg.2009.04.017
Chu, X., J. Zhang, Y. Chi and J. Yang, 2010. An improved method for watershed delineation and computation of surface depression storage. Watershed Manage. DOI: 10.1061/41143(394)100

Farouk, S., F. Ahmad and A.A. Smadi, 2013. Stratigraphy of the middle Eocene-Lower oligocene successions in northwestern and eastern Jordan. J. Asian Earth Sci., 73: 396-408. DOI: 10.1016/j. jseaes.2013.05.005

Galli, P., 1999. Active tectonics along the Wadi ArabaJordan Valley transform fault. J. Geophys. Res., Solid Earth, 104: 2777-2796. DOI: 10.1029/1998 JB900013

Garfunkel, Z., I. Zak and R. Freund, 1981. Active faulting in the Dead Sea Rift. Tectonophysics, 80: 126. DOI: 10.1016/0040-1951(81)90139-6

Guidoboni, E., A. Comastri and G. Traina, 1994. Catalogue of Ancient Earthquakes in the Mediterranean Area up to the 10th Century. 1st Edn., Istituto nazionale di Geofisica, Rome, pp: 504.

Guiraud, R. and W. Bosworth, 1999. Phanerozoic geodynamic evolution of northeastern Africa and the northwestern Arabian platform. Tectonophysics, 315: 73-108. DOI: 10.1016/S0040-1951(99)00293-0

Keller, E. and D. Derecchio, 2013. Tectonic geomorphology of active folding and development of transverse drainage. Geomorphology, 5: 129-147.

Landmann, G., G.M.A. Qudaira, K. Shawabkeh, V. Wrede and S. Kempe, 2002. Geochemistry of the Lisan and Damya Formations in Jordan and implications for palaeoclimate. Q. Int., 89: 45-57.

Marco, S., M. Hartal, N. Hazan, L. Lev and M. Stein, 2003. Archaeology, history and geology of the A.D. 749 earthquake, Dead Sea Transform. Geology, 31: 665-668. DOI: 10.1130/G19516.1

Mather, A.E., 2000. Adjustment of a drainage network to capture induced base-level change: An example from the Sorbas Basin, SE Spain. Geomorphology, 34: 271-289.

Niemi, T.M., H. Zhang, M. Atallah and J.B.J. Harrison, 2001. Late pleistocene and holocene slip rate of the northern Wadi Araba fault, dead sea transform, Jordan. J. Seismol., 5: 449-474. DOI: 10.1023/A: 1011487912054.

Nobre, A.D., L.A. Cuartas, M. Hodnett, C.D. Renno and G. Rodrigues et al., 2011. Height above the nearest drainage-a hydrologically relevant new terrain model. J. Hydrol., 404: 13-29. DOI: 10.1016/j. jhydrol.2011.03.051 
Parrish, J.T. and R.L. Curtis, 1982. Atmospheric circulation, upwelling and organic-rich rocks in the Mesozoic and Cenozoic eras. Palaeogeograp. Palaeoclimatol. Palaeoecol., 40: 31-66.

Powell, J. and B. Moh'd, 2011. Evolution of cretaceous to Eocene alluvial and carbonate platform sequences in central and south Jordan. GeoArabia, 16: 29-82.

Ramasamy, S.M., C. Kumanan, R. Selvakumar and J. Saravanavel, 2011. Remote sensing revealed drainge anomalies and related tectonics of South India. Tectonophysics, 501: 41-51. DOI: 10.1016/j.tecto. 2011.01.011

Sbeinati, M.R., R. Darawcheh and M. Mouty, 2005. The historical earthquakes of Syria; an analysis of large and moderate earthquakes from 1365 B.C. to 1900 A.D. Ann. Geophys., 48: 347-435.

Soille, P., J.V. Vogt and R. Colombo, 2003. Carving and adaptive drainage enforcement of grid digital elevation models. Water Resour. Res., 39: 13661366. DOI: 10.1029/2002WR001879

Stokes, M. and A.E. Mather, 2003. Tectonic origin and evolution of a transverse drainage: The Río Almanzora, Betic Cordillera, Southeast Spain. Geomorphology, 50: 59-81. DOI: 10.1016/S0169555X(02)00208-8

Talling, P.J., M.D. Stewart, C.P. Stark, S. Gupta and S.J. Vincent, 1997. Regular spacing of drainage outlets from linear fault blocks. Basin Res., 9: 275-302. DOI: 10.1046/j.1365-2117.1997.00048.x
Vernant, P., F. Hivert, J. Chery, P. Steer and R. Cattin et al., 2013. Erosion-induced isostatic rebound triggers extension in low convergent mountain ranges. Geol. Soc. Am., 41: 120-124. DOI: 10.1130/G33942.1

Vijayan, S., K. Vani and S. Sanjeevi, 2013. Topographical analysis of lonar crater using Cartosat-1 DEM. J. Indian Soc. Remote Sens., 41: 345-354. DOI: 10.1007/s12524-012-0216-5

Vogt, J.V., R. Colombo and F. Bertolo, 2003. Deriving drainage networks and catchment boundaries: A new methodology combining digital elevation data and environmental characteristics.Geomorphology, 53: 281 - 298. DOI: 10.1016/ S0169-555X(02) 00319-7

Whittle, G.L., A.S. Alsharhan and W.M. El Deeb, 1995. Bio-lithofacies and diagenesis in the early-middle oligocene of Abu Dhabi, United Arab Emirates. Carbonate Evaporites, 10: 54-64. DOI: 10.1007/ BF03175240

Wise, S., 2000. Assessing the quality for hydrological applications of digital elevation models derived from contours. Hydrol. Process., 14: 1909-1929. DOI: $10.1002 / 1099-1085(20000815 / 30) 14: 11 / 12<$ 1909:AID-HYP45>3.0.CO;2-6

Zeiler, M., 1999. Modeling our World: The ESRI Guide to Geodatabase Design. 1st Edn., ESRI, Inc., Redlands, ISBN-10: 1879102625, pp: 199. 